\title{
SERIE DE CASOS: MIELOMA MÚLTIPLE DIFERENCIACIÓN CLÍNICA, DIAGNOSTICA Y TERAPÉUTICAS EN TIEMPOS DE PANDEMIA 2020.
}

\author{
Pinza Luis Alberto ${ }^{1}$, Aguirre Guido Mauricio ${ }^{1 *}$, \\ Leines Nancy Janeth ${ }^{2}$, Jara Valeria Alexandra ${ }^{3}$.
}

DOI: $10.48018 /$ rmv.v32.i1.S11

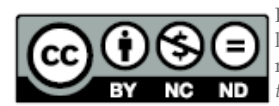

ste artículo está bajo una icencia de Creative Commons de tipo Reconocimiento - No comercial - Sin obras OPEN ACCESS derivadas 4.0 International.

1. Hospital General San Francisco. Médico del Servicio de Medicina Interna. Quito - Ecuador

2. Subcentro de Salud Carcelén. Médico del Servicio de Medicina Familiar. Quito- Ecuador

3. Hospital Docente de Calderón. Médico del Servicio de Cirugía General. Quito-Ecuador

\section{ORCID ID:}

Pinza Luis Alberto

orcid.org/0000-0002-5322-7597

Aguirre Guido Mauricio

orcid.org/0000-0002-8718-1814

Leines Nancy Janeth

orcid.org/0000-0001-9040-7784

Jara Valeria Alexandra

orcid.org/0000-0001-9855-9379

* Corresponding author

Aguirre Guido Mauricio

E-mail: guido_aguirre@hotmail.com

Article history: Manuscript presented at the I Clinical Case Contest - Hospital Vozandes Quito, February 27, 2021.

CARE 2017 Check List statement: The authors have real the CARE 2017 Check List and the manuscript was prepared and revised according to the CARE 2017 Checklist.

Conflict of interest: All authors declared that there are no conflicts of interest.

Financial disclosure: The authors have no financial relationships relevant to this article to disclose.

Forma de citar este artículo: Pinza

LA, Aguirre GM, Leines NJ, Jara

VA. SERIE DE CASOS: MIELOMA

MÚLTIPLE DIFERENCIACIÓN CLÍNICA,

DIAGNOSTICA Y TERAPÉUTICAS EN

TIEMPOS DE PANDEMIA 2020. Rev Med

Vozandes. 2021; 32 (1 Suppl 1): S21-S22

\section{Resumen}

Introducción: El mieloma múltiple es una neoplasia causada por la proliferación de un clon de células plasmáticas que en la mayoría de los casos produce una proteína monoclonal. Por su incidencia disminuida de 4-5 casos por 100000 habitantes.

Descripción del Caso: En el Hospital General San Francisco QuitoEcuador se diagnosticó durante este tiempo de pandemia: tres casos de Mieloma Múltiple, con presentación diversa tanto en la manifestaciones clínicas como laboratoriales y radiográficas, llevándonos a realizar una serie de casos clínicos como objetivo de diferenciar el tipo de clínica, diagnóstica y terapéutica en tiempos de pandemia en el 2020. Encontrándose diagnósticos al ingreso distintos como Síndrome Coronario Agudo, Pancreatitis Aguda e Insuficiencia cardiaca, que posteriormente fueron descartados y evidenciando en general un dolor óseo, hiperamilasemia e hiperglobulinemia, con cambios de imagen tanto en sacabocados óseos y fracturas patológicas que llevaron a la sospecha de Mieloma Múltiple y realización de medulograma para diagnóstico definitivo. El tratamiento realizado por subespecialidad se realizará sin complicaciones.

Conclusión: La principal característica son fracturas patológicas que pueden presentarse en forma de dolor agudo o crónico, además relacionada a con otras patologías; y al no estar presente el resto de manifestaciones clínicas que menciona la literatura. También cabe mencionar que la hiperamilasemia fue un factor encontrado en nuestros casos que estudios futuros se podría relacionarse como factor pronóstico y mortalidad en el Mieloma múltiple 


\begin{tabular}{r|l}
\hline & Abstract \\
& CASE SERIES: MULTIPLE MYELOMA \\
& CLINICAL DIFFERENTIATION, DIAGNOSIS AND \\
$\begin{array}{r}\text { Keywords: Multiple } \\
\begin{array}{r}\text { Myeloma, Hyperamylase- } \\
\text { mia, Hyperglobulinemia, } \\
\text { Sars Cov2, pathological } \\
\text { fractures. }\end{array}\end{array}$ & THERAPEUTICS IN TIMES OF PANDEMIC 2020. \\
\hline
\end{tabular}

Introduction: Multiple myeloma is a neoplasm caused by the proliferation of a clone of plasma cells that in most cases produce a monoclonal protein. Due to its decreased incidence of 4-5 cases per 100,000 inhabitants.

Case description: The General Hospital San Francisco Quito-Ecuador was diagnosed during this time of pandemic: three cases of Multiple Myeloma, with diverse presentation both in clinical manifestations, laboratories and radiographs, taking us to carry out a series of clinical cases with the objective of differentiating the type of clinic, diagnosis and therapy in times of pandemic in 2020. Finding different diagnoses at admission such as acute coronary syndrome, acute pancreatitis and heart failure, which were later discarded and evidenced in general bone pain, hyperamylasemia and hyperglobulinemia, with image changes both in bone punches and pathological fractures that led to the suspicion of Multiple Myeloma and performance of a medullogram for definitive diagnosis. The subspecialty treatment will run without complications.

Conclusion: The main characteristics are pathological fractures that can present in the form of acute or chronic pain, as well as related to other pathologies; and since the rest of the clinical manifestations mentioned in the literature were not present. It is also worth mentioning that hyperamylasemia was a factor found in our cases that future studies could be related as a prognostic factor and mortality in multiple myeloma 